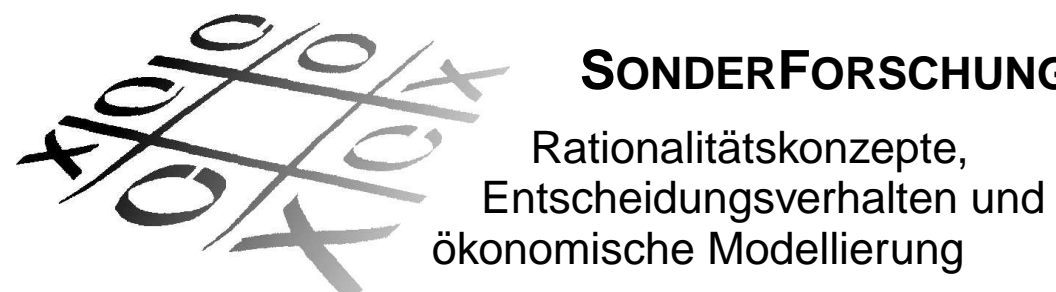

No. $04-11$

Disclosure Regimes and Corporate Governance

Jens Wüstemann*

April 2004

Financial support from the Deutsche Forschungsgemeinschaft, SFB 504, at the University of Mannheim, is gratefully acknowledged.

*Lehrstuhl für ABWL und Wirtschaftsprüfung/Sonderforschungsbereich 504, email: wuestemann@bwl.uni-mannheim.de

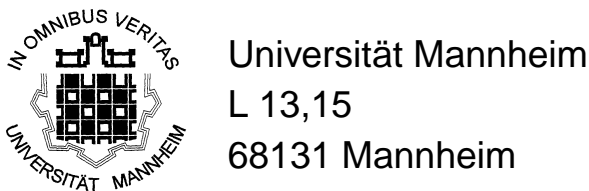




\title{
Disclosure Regimes and Corporate Governance
}

by

\author{
JENS WÜSTEMANN
}

\section{Introduction}

This paper analyzes some aspects of the relationship of variant international disclosure regimes and corporate governance. In considering informational aspects of corporate governance from an institutional perspective, I follow the definition of corporate governance set out by SHLEIFER AND VISHNY [1997, p. 737], who define corporate governance as "the ways suppliers of finance to corporations assure themselves of getting a return of their investment". The various ways for a supplier of finance to ensure getting an appropriate return include, e.g., decision rights, control rights, protection rights, payout rights, and monitoring rights, some of which naturally might overlap.

However, to exercise control and to - actively or passively - monitor management effectively, financial contracting parties also need value-relevant information to base their individual decisions upon. The allocation of information rights directly affects the exertion of control and therefore, ultimately, the distribution of future payouts for investors. Information rights and the flow of information within the firm and to outside parties consequently constitute important elements of corporate governance. A comparative institutional assessment of disclosure regimes shows that internationally these rights to obtain information are allocated in different modes. I argue that this varying distribution of information rights can be interpreted as a function of different - but probably somewhat consistent - systems of corporate governance in national financial systems.

I understand the term "disclosure regime" in a broad sense. A disclosure regime encompasses all legally recognized information claims a system of corporate governance or a financial system furnishes financial contracting parties with. This includes private information channels (see LEUZ AND WÜSTEMANN [2003]). An information claim is an enforceable legitimate information interest. Typically, investors' information interests lie in the financial consequences of realized or planed dispositions of firm's management. The disclosure regime comprises public disclosure, induced, say, by securities regulation, but it also includes disclosure duties of management towards outside directors (or the supervisory board in a two-tiers system), and information rights of banks (see HOMMELHOFF [2000]). Traditional instruments of financial accounting such as

\footnotetext{
${ }^{1}$ See SChMidt [1997], TiRole [2001], and ZingaLes [1998] for wider definitions.
} 
accounting numbers constitute but a part of a disclosure regime. ${ }^{2}$ In restricting the set of decision-relevant information, disclosure regimes also restrict the set of means that enable protection of interests of the financial contracting parties.

In comparing international institutional designs from a contractual perspective, the agenda of the New Institutional Economics has proven to be fruitful: ${ }^{3}$ It has always been the agenda of this school to study ,contracting in its entirety“ (WILLIAMSON [1984, p. 210]); New Institutional Economics is strongly influenced by the notion of the firm as a "nexus of contracts" (JENSEN and MECKLING [1976, p. 310]; see also, e. g., SCHANZE [2003]). In a world of incomplete contracts, however, underlying "constitutions" become important (see also, e. g., EASTERBROOK AND FISCHEL [1991]). KIRCHNER [1997] argues that accounting regulation or securities regulation can be interpreted as underlying constitutions which form an implicit part of a financial contract. Accounting regulation defines the basic set of important financial key numbers the parties can contract on, for instance for pay-out restrictions. Similarly, securities regulation defines the set of publicly available information for actual or potential suppliers of finance to public corporations. Disclosure regimes are in a certain sense thus embedded in corporate governance. Disclosure duties imposed on a firm by, for instance, banking acts (see infra) probably don't belong to corporate governance in a narrow sense. But they nevertheless influence the degree of informational asymmetries between financial contracting parties and the firm and thus affect the way investors "assure themselves of getting a return of their investment" (see supra). The nexus of information rights formed by accounting and disclosure regulation is therefore crucial to determine "power" in the firm. Alternatively, national disclosure regimes can be explained by existent distribution of power to key contracting parties. ${ }^{4}$

Within the framework of the New Institutional Economics, disclosure also serves as an important means of measurement. With regard to product markets, BARZEL [1982] argues that brand names reduce measurement costs and interprets brand names as ways of rational suppression of information. Under certain conditions, therefore, it is "expected that some readily obtainable information will be suppressed to preempt opportunities for excessive measurement" (FURUBOTN and RICHTER [1997, p. 293]). This should be valid for the organization of financial markets, too: Internationally accepted sets of accounting and auditing standards may equally reduce measurement costs of the quality of securities.

The following section sketches the paradigm of externalization of value-relevant information in a system of outsider control and stresses the role of complementary institutions. Section 3 outlines some differences in a model in which investors with privileged information represent key contracting parties and exercise control. Section 4 briefly emphasizes the need of detailed and appropriate

2 Similarily, the term "financial reporting" accentuates the need of soft information and continous information as supplementary means of investor information (BEAVER [1989/1998]).

3 See, e.g., FURUBOTN AND RICHTER [1997] for an assessment of the New Institutional Economics.

${ }^{4}$ See for some discussions FURUBOTN AND RiCHTER [1997, pp. 292ff]. 
disclosure rules both within the firm and towards markets. Finally, section 5 points out that realistic assessment of control regimes and recommendations for institutional design also need to encompass behavioral aspects of decision making. I argue that from a behavioral law and economics standpoint under certain circumstances incentives to disclose information to monitoring parties may fail due to irrational evaluation and response to risk. Thus, in addition to meaningful disclosure systems, corporate governance should also take into account some more convincing assumptions of the processing of value-relevant information both within the firm and towards markets.

\section{Externalization of Information and Outsider Control}

In the mid- $19^{\text {th }}$ century, corporations of the modern type began to evolve in the U.S. and to influence economic development of the national economy significantly (see CHANDLER [1990]). In 1932, Berle and Means made, so to speak, a historical observation when they stated in their seminal book that the modern corporation was characterized by dispersed ownership and that in contrast to family-dominated traditional corporations' management by then didn't possess significant parts of the shares. They concluded famously that "separation of ownership from control produces a condition where the interest of owner and of ultimate manager may, and often do, diverge" (BERLE AND MEANs [1932, p. 6]; see also SMITH [1776/1991], BLAIR [1995]). In a stylized way, the U.S. financial system is until today the prototype of a market-oriented financial system: ${ }^{5}$ A large number of corporations is listed and publicly traded, households and financial institutions keep shares directly. Corporations are financed at arm's length. The typical ownership structure is characterized by dispersed ownership and no substantial cross-holdings (LA PORTA et al. [1999]). Equity capital plays a relatively more important role than debt capital. This system of monitoring structures is sometimes referred to as a system of outsider control.

In consequence, corporate governance in the U.S. primarily "refers to the defense of shareholders' interest" (TIROLE [2001, p. 1]). "Creating shareholder value" (RAPPAPORT [1998]) was, so to speak, always the prevailing business strategy. Extensive direct protection rights of minority shareholders belong to the important means of defense of shareholder interests. But public dissemination of information also plays a crucial role in the U.S. ever since the enactments of the Securities Act of 1933 and the Securities Exchange Act of 1934. In a well-known remark Justice Brandeis stated even as early as 1914 that ,[p]ublicity is justly commended as a remedy for social and industrial diseases. Sunlight is said to be the best of disinfectants". U.S. securities regulation rests on a philosophy of full and fair disclosure. ${ }^{6}$ In Basic, Inc. v. Levinson (U.S. 224, 234) the Supreme Court emphasized that Congress had adopted a policy of ,disclosure, and not paternalistic withholding of accurate information“. For a typical Berle-Means-

5 See Franks AND MAYer [1994], BerglÖF [1997]; see also AlLEN AND GALE [2001].

${ }^{6}$ See Basic, Inc. v. Levinson, 485 U.S. 224, 234 (1988). 
corporation the philosophy of full and fair disclosure serves to reduce agency costs that arise out of the separation of ownership and control. The protection by means of externalization of information works at least threefold: The individual investor is protected from misleading statements and from the omission of material facts by a corporation. In semi-efficient capital markets individual investors are also protected by (fair) market prices of shares which reflect all publicly available information and which may replace individual evaluation of decision-relevant information. Finally, the wide public dissemination of valuerelevant information enables an active market for corporate control which probably constitutes the core of the monitoring structure of an outside-control regime (takeovers, proxy fights, and leveraged buy-outs). However, it would be naïve to overinterpret the notion of "full" disclosure. In fact, informational asymmetries between management (insiders) and the market (outsiders) will remain in spite of detailed public disclosure. Also, the line between imposed disclosure duties and information not required to be disclosed is fuzzy even in U.S. securities regulation (LOSS AND SELIGMAN [2001]).

Recent research has emphasized the complementary function of the overall institutional infrastructure (BALL [2001]) and the role of enforcement institutions and market-oriented incentive structures such as class actions for functioning equity markets (e. g., WÜSTEMANN [2002]). The different institutional analyses show equally that efficient securities markets are the result of a variety of institutional mechanisms and that the "magic" of strong securities markets "does not appear in unregulated markets" (BLACK [2001, p. 782]). This insight is of importance for economies that intend to shift towards a market-oriented financial system, such as some countries of the E.U., including Germany (see also SCHMIDT AND TYRELL [1997]).

In summary, the modus of externalization of information with its emphasis on public disclosure and complementary infrastructure can be interpreted as an institutional solution to corresponding agency and monitoring problems in modes of corporate governance attached to typical financing patterns of a marketoriented financial system. The institutional infrastructures guarantee that key contracting financial parties are well-informed (and well protected). ${ }^{7}$ Interestingly, important ways of monitoring (by the market for corporate control) are exercised by means of market regulation (securities regulation) and less by means of corporate governance (corporation law).

\section{Internalization of Information and Insider Control}

Even for large multinational corporations the financing patterns of the type just mentioned are not equally valid on an international scale (LAPORTA et al. [1999]; PRIGGE [1998]). In contrast to the market-oriented financial system of the U.S., the German financial system, for instance, traditionally has been characterized by a domination of banks (see also SCHMIDT AND TYRELL [1997]): The direct raising of capital using the capital market is of minor importance. Rather, long term

\footnotetext{
${ }^{7}$ See LEUZ AND WÜSTEMANN [2003] for details and discussion.
} 
financing by house banks - in the sense of relationship lending - is the most important source of capital. The financial system is characterized by crossholdings and a heavy concentration of ownership (families, banks, and insurance companies).

Not surprisingly, a different control structure has developed historically, which sometimes is referred to as a regime of "insider control" (FRANKS AND MAYER [1994], BERGLÖF [1997]) or, with regard to the different role of banks and intermediated financing in general, as "informed capital" (TIROLE [2001, p. 8]). Insider control means that a smaller group of better informed parties (representatives of families, banks, and insurance companies) exercises significant control of management, for instance by means of membership in the supervisory board. The concentrated ownership at least prevents some monitoring problems typically attached to the Berle-Means-corporation with its dispersed ownership structure (and leads to different problems ${ }^{8}$ ).

It is plausible to assume that in a functioning financial system information flows are all the same conducted to key contracting parties. One can therefore expect a less developed public disclosure regime, but, as a substitute, a developed insider information system. Using the example of the German financial system, LEUZ AND WÜSTEMANN [2003] provide institutional and empirical evidence supporting both corresponding hypotheses and examine the institutionally guaranteed information rights in an insider regime. They show that Germany has an elaborated system of legalized and explicit reporting and disclosure duties within the firm that disseminates decision-relevant information to key contracting parties (but not to the public). The representation of major shareholders and major creditors in the supervisory board (and possibly in the audit committee) belongs to these private information systems. With respect to banks, German banking regulation even obliges any bank which intends granting a credit of more than $€ 250,000$ to have credit-relevant information of the borrowing company disclosed by means of annual reports and supplementary information which should include, e. g., auditor's reports (Prüfungsberichte), minutes of balance sheet committee meetings (Bilanzgespräche), and prospective budgets (Finanzpläne). ${ }^{9}$ The type of relationship lending typical for the German financial system offers the house bank also useful information by means of historical records of actual cash flows of borrowers that document credit ratings of the past (e. g., credit transfers and paying habits). One could equally add information circulated to labor as a further key contracting party: Due to the German system of co-determination, labor is also represented in the supervisory board and thereby has access to privileged information (see, e.g., FUROBOTN AND RICHTER [1997, pp. 389-404]). As a very important information instrument for the members of the supervisory board, the German (written) auditor's report (Prüfungsbericht) gives detailed analytical account of the firms financial position, past performance, critical accounting

8 For instance to the problem of "who monitors the monitors" (DIAMOND [1984]; AlLEN AND GALE [2001, p. 105]).

${ }^{9}$ See $\S 18$ of the Act Regulating Banking and Credit Business (Kreditwesengesetz). 
policies, and especially shall reveal any dangers of a possible future financial distress to the supervisory board (whistle-blowing function). ${ }^{10}$

\section{Information Duties and Decision Usefulness}

Corporate governance should not only focus on information flows and information duties as such but also on the informational contents transmitted. Although the decision-usefulness principle forms a major principle (and sometimes even overriding principle) for most regulations of corporate financial reporting, ${ }^{11}$ accounting and disclosure rules sometimes give the impression of „,cookbook accounting”, especially in countries dominated by a case lawapproach. This leads on the one hand to a vast variety of information to investors that could confirm the notion of information overflow in securities markets. On the other hand, disclosure regimes nevertheless often lack important decisionrelevant information. Comprehensive and comparative discussions of critical accounting policies and accounting choices, for instance, should normally enrich the accompanying notes of any annual report. A standardized and written report in which auditors inform the audit committees of their statutory audit in a legalized way could be a form to match the legal demands imposed by the Sarbanes-Oxley Act of 2002 in the U.S. ${ }^{12}$ In German annual reports, on the other hand, forwardlooking information and a standardized report comparable to the Management's Discussion and Analysis (MD\&A) in Item 303 of regulation S-K would be desirable. To avoid information overflow and at the same time improve corporate reporting, a consistent system of information duties de lege lata that follows informational needs of investors is necessary. ${ }^{13}$ Standard setting in the area of accounting and disclosure by private standard setting bodies which are exposed to extreme pressures certainly does not make the necessary reforms easier.

\section{Information Processing and Behavioral Law and Economics}

Since the seminal papers of COASE [1960] and CALABRESI [1961], the Law and Economics-approach has become a powerful tool in the analysis of the consequences of legal rules and institutions (see, e.g., POSNER [1973/1998], COOTER AND ULEN [2000]). It showed that the effects of legal rules and institutions can be compared with those of prices. Individual actors respond to changes in legal rules, adjusting supply and demand of their intended actions. An increase in the penalty for the issuance of misleading statements regarding future

10 See also SUNDER [1997] for a discussion of the role of auditors in the context of corporate control.

11 See, e.g., Financial Accounting Standards BoARD [2002], International ACCOUNTING STANDARDS BoARD [2002], $4^{\text {th }}$ and $7^{\text {th }}$ European Directives, and $\S \S 242,243$, and 264 of the German Commerical Code for Germany. See also MOXTER [1966].

${ }_{12}$ As an example could serve the German auditor's report.

13 See MOXTER [2003] for a comprehensive system of German reporting duties de lege lata. See for discussion also WÜSTEMANN [2002]. 
prospects of the firm will thus lower the expected utility of the action and thereby reduce the willingness of management to mislead financial markets. However, neo-classical Law and Economics is based on rather strong rationality assumptions, that from a viewpoint focusing on precisely the effects of rules (and less on normative considerations) sometimes lead to false recommendations. As a reaction to failures in the predictions made by standard expected utility theory, KAHNEMAN AND TVERSKY [1979] introduced insights of psychology and sociology to economic analysis. Since then, Behavioral Economics has identified a multitude of systematic effects (such as framing, commitment bias, overconfidence, hindsight bias, and anchoring) that shape human action but are not in conformity with traditional models of utility-maximizing man.

The approach of Behavioral Law and Economics has applied those insights to legal issues. ${ }^{14}$ The implications of Behavioral Law and Economics for the design of disclosure regimes and corporate governance mechanisms are straightforward: If information flows need to be evaluated by their addressee and, ultimately, shall lead to consequences in their response (decision), then cognitive biases which contradict classical assumptions of human behavior need to be taken into account, too. This is especially valid regarding substantial business and legal risks. With respect to the processing of information to main monitoring parties, evaluation and response to risk serves as good example. PAINTER [2003] argues that cognitive biases lead to deficiencies in the evaluation of risk and to undesirable relating responses. Managers, for instance, who are in a loss frame, will tend to take higher risks than they would under normal conditions. Additionally, they will not process bad news to the market even though they are obliged to. He concludes that in these cases gatekeepers (auditors and lawyers) who are less subject to cognitive biases should be committed to report to outside directors (or the supervisory board) and that responsibility should be shifted to those parties which are not affected by biases. A multitude of corporate governance rules regulating auditors and lawyers in the U.S. and E.U. can be explained as strategies to avoid cognitive biases in the response to risk. Normatively spoken, cognitive biases should be considered with respect to the making of new rules.

Cognitive biases have also implications for the processing of new information to securities markets and in consequence for possible claims of people that are legally entitled to have the information sooner than they actually get it and may therefore raise claims against the corporation (PAINTER [2003, p. 2]). But behavioral research has impacts for the functioning of public disclosure regimes, too. If financial markets are at least not generally semi-efficient, as recent research in Behavioral Finance (see SHLEIFER [1999] and GLASER, NÖTH, AND WEBER [2004]) suggests, then some rules protecting investors - such as the fraud-on-themarket theory-may lack their theoretical foundation (LANGEVOORT [1992]). Short-term inefficiencies of capital markets may also somewhat limit the beneficial effects of a market for corporate control and emphasize the need of complementary mechanisms of insider control.

14 See, e.g., Jolls, Sunstein, AND Thaler [1998]; LANGEVOORT [1998]; KOROBKIN AND ULEN [2000]; see for a critical appraisal, e.g., POSNER [1998]. 


\section{Summary}

(1) Collapses of large companies in both the bank-oriented and the marketoriented financial systems reveal deficiencies of corporate governance worldwide and lead to legislative proposals in the U.S. and the E.U.

(2) Both the public disclosure regime and information duties towards main monitoring parties (including outside directors) seem to be of equal importance for successful corporate governance. Research also emphasizes the importance of complementary institutions such as class actions, enforcement institutions (like the SEC), and the institutional infrastructure.

(3) Regulation of accounting and disclosure, however, sometimes resembles a cookbook and needs to be transformed in a more principle-based and deductive system of disclosure duties.

(4) Institutional design of corporate governance should be based on realistic assumptions of human decision behavior. Here, the role of independent auditors and lawyers is of great importance to corporate governance, especially in times of corporate crises.

(5) The New Institutional Economics still proves to provide a comprehensive analytical framework for positive and normative research issues in corporate governance.

\section{References}

Allen, F. AND D. Gale [2001], Comparing Financial Systems, MIT Press: Cambridge, MA.

BALL, R. [2001], "Infrastructure Requirements in the Area of Accounting and Disclosure Policy”, pp. 127-169 in: R. Litan and R. Herring (eds), BrookingsWharton Papers on Financial Services, Brookings Institution Press: Washington, DC.

BARZEL, Y. [1982], Measurement Cost and the Organization of Markets, Journal of Law and Economics, 25, 27-48.

BeAVER, W. H. [1989/1998], Financial Reporting. An Accounting Revolution. $3^{\text {rd }}$ ed., Prentice Hall: Upper Saddle River.

BERGLÖF, E. [1997], "A Note on the Typology of Financial Systems", pp. 151164 in K. J. Hopt and E. Wymeersch (eds.), Comparative corporate governance: Essays and materials, Gruyter: Berlin et al.

Berle, A. A. And G. C. Means [1932], The Modern Corporation and Private Property, $2^{\text {nd }}$ ed., Harcourt, Brace \& World: New York.

BLACK, B. S. [2001], "The Legal and Institutional Preconditions for Strong Securities Markets”, UCLA Law Review, 48, 781-855. 
BlaIR, M. [1995], Ownership and Control: Rethinking Corporate Governance for the Twenty-First Century, Brookings Institution: Washington, D. C.

CALABRESI G. [1961], "Some Thoughts on Risk Distribution and the Law of Torts", Yale Law Journal, 70, 499-553.

Chandler, A. [1990], Scale and Scope. The Dynamics of Industrial Capitalism, The Belknap Press: Cambridge, MA?

COASE, R. [1960], "The Problem of Social Cost", Journal of Law and Economics, $3,1-44$.

CoOter, R. AND T. Ulen [2000], Law and Economics, $3^{\text {rd }}$ ed., Addison-Wesley: Reading, MA.

DiAmOND, D. [1984], "Financial Intermediation and Delegated Monitoring", Review of Economic Studies, 51, 393-414.

EASTERbrook, F. H. AND D. R. Fischel [1991], The Economic Structure of Corporate Law, Harvard University Press: Cambridge, MA.

Financial Accounting Standards BoArd [2002], Original Pronouncements, Volume III, John Wiley \& Sons, Inc: New York.

FRANKS, J. AND C. MAYER [1994], "Corporate Control: A Comparison of Insider and Outsider Systems,” Working Paper, London Business School.

FURUBOTN, E. G. AND R. RICHTER [1997], Institutions and Economic Theory: The Contribution of the New Institutional Economics, University of Michigan Press: Ann Arbor, MI.

Glaser, M., M. NÖTH, AND M. Weber [2004], "Behavioral Finance", forthcoming in: D. J. Koehler et al. (eds), Blackwell Handbook of Judgment and Decision Making, Blackwell: Oxford (forthcoming).

HoMmelHOFF, P. [2000], „Anlegerinformationen im Aktien-, Bilanz- und Kapitalmarktrecht", Zeitschrift für Unternehmens- und Gesellschaftsrecht, 29, 748-775.

INTERNATIONAL ACCOUNTING STANDARDS BOARD [2003], International Accounting Standards 2002, International Accounting Standards Board: London.

Jensen, M. C. AND W. H. Meckling [1976], "Theory of the Firm: Managerial Behavior, Agency Costs, and Ownership Structure," Journal of Financial Economics, 3, 305-360.

Jolls, C., C. R. Sunstein, AND R. H. Thaler [1998], “A Behavioral Approach to Law and Economics”, pp. 13-58 in: C. R. Sunstein (ed.), Behavioral Law and Economics, Cambridge University Press, Cambridge, UK.

Kahneman, D. And A. TVERSKY [1979], "Prospect Theory: An Analysis of Decision under Risk", Econometrica, 47, 263-292.

KIRCHNER, C. [1997]: "Bilanzrecht und Institutionenökonomik: Interdisziplinäre Überlegungen,” pp. 267-283 in: W. D. Budde et al. (eds.), Handelsbilanzen und Steuerbilanzen, IDW-Verlag: Düsseldorf.

Korobkin, R. B. AND T. S. Ulen [2000], "Law and Behavioral Science: Removing the Rationality Assumption from Law and Economics", California Law Review, 88, 1051-1144.

La Porta, R., F. Lopez-De-Silanes, A. Shleifer, AND R. Vishny [1999], "Corporate Ownership around the World", Journal of Finance, 54, 471-517. 
Langevoort, D. C. [1992], "Theories, Assumptions, and Securities Regulation: Market Efficiency Revisited”, University of Pennsylvania Law Review, 140, 851-920.

- [1998] "Behavioral Theories of Judgement and Decision Making in Legal Scholarship: A Literature Review”, Vanderbilt Law Review, 51, 1499-1540.

LEUZ, C. AND J. WÜSTEMANN [2003], „The Role of Accounting in the German Financial System",in: J. Krahnen and R. H. Schmidt (eds), The German Financial System, Oxford University Press: Oxford and New York (forthcoming).

Loss, L. AND J. Seligman [2001], Fundamentals of Securities Regulation, $4^{\text {th }}$ ed., Aspen Law and Business: New York.

MOXTER, A. [1966], „Die Grundsätze ordnungsmäßiger Bilanzierung und der Stand der Bilanztheorie“, Zeitschrift für betriebswirtschaftliche Forschung, 18, $28-59$.

_ [2003], Grundsätze ordnungsgemäßer Rechnungslegung, Düsseldorf: IDW-Verlag.

PAINTER, R. W. [2003], "Jurisdictional Competition, Convergence, and Auditors in the U.S. and E.U.," Working Paper, University of Illinois, College of Law.

Posner, R. A. [1973/1998], Economic Analysis of Law, $5^{\text {th }}$ ed., Aspen Publishers: New York.

[1998], "Rational Choice, Behavioral Economics, and the Law", Stanford Law Review, 50, 1551-1575.

PRIGGE, S. [1998], “A Survey of Corporate Governance”, pp. 943-1044 in: K. J. Hopt et al. (eds), Comparative Corporate Governance - The State of the Art and Emerging Research, Clarendon Press: Oxford.

RAPPAPORT, A. [1998], Creating Shareholder Value. The New Standard for Business Performance, $2^{\text {nd }}$ ed., New York: Free Press.

SCHANZE, E. [2003], "A Model of Shareholding", Journal of Institutional and Theoretical Economics, (forthcoming).

SCHMIDT, R. H. [1997], "Corporate Governance: The Role of Other Constituencies", pp. 61-74 in: A. Pezard et al. (eds), Corporate Governance: Les Perspectives Internationales, Montchrestien: Paris.

- AND M. Tyrell (1997), "Financial Systems, Corporate Finance, and Corporate Governance," European Financial Management, 3, 333-361.

SHLEIFER, A. [1999], Inefficient Markets: An Introduction to Behavioral Finance, Oxford University Press: Oxford and New York.

— AND R. VISHNY [1997], "A Survey of Corporate Governance”, Journal of Finance, 52, 737-783.

Smith, A. [1776/1991], An Inquiry into the Nature and Causes of the Wealth of Nations, Prometheus Books (Great Mind Series): New York.

Sunder, S. [1997], Theory of Accounting and Control, South West College Publishing: Cincinnati.

TIROLE, J. [2001], „Corporate Governance“, Econometrica, 69, 1-35.

Williamson, O. E. [1984], "The Economics of Governance", Journal of Institutional and Theoretical Economics, 140, 195-223.

WÜSTEMANN, J. [2002], Institutionenökonomik und internationale Rechnungslegungsordnungen, Mohr-Siebeck: Tübingen. 
ZINGALES, L. [1998], „Corporate Governance“, pp. 497-502 in: P. Newman (ed.), The New Palgrave Dictionary of Economics and the Law, Macmillan: London.

\author{
Jens Wüstemann \\ Fakultät für Betriebswirtschaftslehre \\ Universität Mannheim \\ A 5,6 \\ 68131 Mannheim \\ Germany \\ E-mail: \\ wuestemann@bwl.uni-mannheim.de
}




\begin{tabular}{|c|c|c|}
\hline Nr. & Author & Title \\
\hline $04-25$ & $\begin{array}{l}\text { Martin Weber } \\
\text { Jens Wuestemann }\end{array}$ & $\begin{array}{l}\text { Bedeutung des Börsenkurses im Rahmen der } \\
\text { Unternehmensbewertung }\end{array}$ \\
\hline $04-24$ & Hannah Hörisch & Does foreign aid delay stabilization \\
\hline $04-23$ & $\begin{array}{l}\text { Daniel Schunk } \\
\text { Joachim Winter }\end{array}$ & $\begin{array}{l}\text { The Relationship Between Risk Attitudes and } \\
\text { Heuristics in Search Tasks: A Laboratory } \\
\text { Experiment }\end{array}$ \\
\hline $04-22$ & Martin Hellwig & $\begin{array}{l}\text { Risk Aversion in the Small and in the Large When } \\
\text { Outcomes Are Multidimensional }\end{array}$ \\
\hline $04-21$ & $\begin{array}{l}\text { Oliver Kirchkamp } \\
\text { Eva Poen } \\
\text { J. Philipp Reiß }\end{array}$ & Bidding with Outside Options \\
\hline $04-20$ & Jens Wüstemann & $\begin{array}{l}\text { Evaluation and Response to Risk in International } \\
\text { Accounting and Audit Systems: Framework and } \\
\text { German Experiences }\end{array}$ \\
\hline 04-19 & Cornelia Betsch & $\begin{array}{l}\text { Präferenz für Intuition und Deliberation (PID): } \\
\text { Inventar zur Erfassung von affekt- und } \\
\text { kognitionsbasiertem Entscheiden }\end{array}$ \\
\hline 04-18 & Alexander Zimper & Dominance-Solvable Lattice Games \\
\hline $04-17$ & $\begin{array}{l}\text { Volker Stocké } \\
\text { Birgit Becker }\end{array}$ & $\begin{array}{l}\text { DETERMINANTEN UND KONSEQUENZEN } \\
\text { DER UMFRAGEEINSTELLUNG. } \\
\text { Bewertungsdimensionen unterschiedlicher } \\
\text { Umfragesponsoren und die Antwortbereitschaft der } \\
\text { Befragten }\end{array}$ \\
\hline $04-16$ & $\begin{array}{l}\text { Volker Stocké } \\
\text { Christian Hunkler }\end{array}$ & $\begin{array}{l}\text { Die angemessene Erfassung der Stärke und } \\
\text { Richtung von Anreizen durch soziale Erwünschtheit }\end{array}$ \\
\hline $04-15$ & $\begin{array}{l}\text { Elena Carletti } \\
\text { Vittoria Cerasi } \\
\text { Sonja Daltung }\end{array}$ & $\begin{array}{l}\text { Multiple-bank lending: diversification and } \\
\text { free-riding in monitoring }\end{array}$ \\
\hline $04-14$ & Volker Stocké & $\begin{array}{l}\text { The Interdependence of Determinants for the } \\
\text { Strength and Direction of Social Desirability Bias } \\
\text { in Racial Attitude Surveys }\end{array}$ \\
\hline
\end{tabular}




\begin{tabular}{|c|c|c|}
\hline $\mathrm{Nr}$. & Author & Title \\
\hline $04-13$ & $\begin{array}{l}\text { Mei Wang } \\
\text { Paul Fischbeck }\end{array}$ & $\begin{array}{l}\text { Evaluating Lotteries, Risks, and Risk-mitigation } \\
\text { Programs No A Comparison of China and the } \\
\text { United States }\end{array}$ \\
\hline $04-12$ & $\begin{array}{l}\text { Alexander Ludwig } \\
\text { Torsten Sløk }\end{array}$ & $\begin{array}{l}\text { The relationship between stock prices, house prices } \\
\text { and consumption in OECD countries }\end{array}$ \\
\hline $04-11$ & Jens Wüstemann & Disclosure Regimes and Corporate Governance \\
\hline 04-10 & $\begin{array}{l}\text { Peter Albrecht } \\
\text { Timo Klett }\end{array}$ & $\begin{array}{l}\text { Referenzpunktbezogene risikoadjustierte } \\
\text { Performancemaße: Theoretische Grundlagen }\end{array}$ \\
\hline 04-09 & Alexander Klos & $\begin{array}{l}\text { The Investment Horizon and Dynamic Asset } \\
\text { Allocation - Some Experimental Evidence }\end{array}$ \\
\hline 04-08 & $\begin{array}{l}\text { Peter Albrecht } \\
\text { Cemil Kantar } \\
\text { Yanying Xiao }\end{array}$ & $\begin{array}{l}\text { Mean Reversion-Effekte auf dem deutschen } \\
\text { Aktienmarkt: Statistische Analysen der } \\
\text { Entwicklung des DAX-KGV }\end{array}$ \\
\hline 04-07 & Geschäftsstelle & Jahresbericht 2003 \\
\hline 04-06 & Oliver Kirchkamp & $\begin{array}{l}\text { Why are Stabilisations delayed - an experiment } \\
\text { with an application to all pay auctions }\end{array}$ \\
\hline 04-05 & $\begin{array}{l}\text { Karl-Martin Ehrhart } \\
\text { Marion Ott }\end{array}$ & Auctions, Information, and New Technologies \\
\hline 04-04 & Alexander Zimper & $\begin{array}{l}\text { On the Existence of Strategic Solutions for Games } \\
\text { with Security- and Potential Level Players }\end{array}$ \\
\hline $04-03$ & Alexander Zimper & $\begin{array}{l}\text { A Note on the Equivalence of Rationalizability } \\
\text { Concepts in Generalized Nice Games }\end{array}$ \\
\hline 04-02 & Martin Hellwig & $\begin{array}{l}\text { The Provision and Pricing of Excludable Public } \\
\text { Goods: Ramsey-Boiteux Pricing versus Bundling }\end{array}$ \\
\hline 04-01 & $\begin{array}{l}\text { Alexander Klos } \\
\text { Martin Weber }\end{array}$ & $\begin{array}{l}\text { Portfolio Choice in the Presence of Nontradeable } \\
\text { Income: An Experimental Analysis }\end{array}$ \\
\hline 03-39 & $\begin{array}{l}\text { Eric Igou } \\
\text { Herbert Bless }\end{array}$ & $\begin{array}{l}\text { More Thought - More Framing Effects? Framing } \\
\text { Effects As a Function of Elaboration }\end{array}$ \\
\hline
\end{tabular}




\begin{tabular}{|c|c|c|}
\hline Nr. & Author & "Title \\
\hline $03-38$ & $\begin{array}{l}\text { Siegfried K. Berninghaus } \\
\text { Werner Gueth } \\
\text { Annette Kirstein }\end{array}$ & $\begin{array}{l}\text { Trading Goods versus Sharing Money - An } \\
\text { Experiment Testing Wether Fairness and Efficiency } \\
\text { are Frame Dependent }\end{array}$ \\
\hline $03-37$ & $\begin{array}{l}\text { Franz Urban Pappi } \\
\text { Thomas Gschwend }\end{array}$ & $\begin{array}{l}\text { Partei- und Koalitionspräferenzen der Wähler bei } \\
\text { der Bundestagswahl } 1998 \text { und } 2002\end{array}$ \\
\hline $03-36$ & Martin Hellwig & $\begin{array}{l}\text { A Utilitarian Approach to the Provision and Pricing } \\
\text { of Excludable Public Goods }\end{array}$ \\
\hline $03-35$ & Daniel Schunk & $\begin{array}{l}\text { The Pennsylvania Reemployment Bonus } \\
\text { Experiments: How a survival model helps in the } \\
\text { analysis of the data }\end{array}$ \\
\hline $03-34$ & $\begin{array}{l}\text { Volker Stocké } \\
\text { Bettina Langfeldt }\end{array}$ & $\begin{array}{l}\text { Umfrageeinstellung und Umfrageerfahrung. Die } \\
\text { relative Bedeutung unterschiedlicher Aspekte der } \\
\text { Interviewerfahrung für die generalisierte } \\
\text { Umfrageeinstellung }\end{array}$ \\
\hline $03-33$ & Volker Stocké & $\begin{array}{l}\text { Measuring Information Accessibility and Predicting } \\
\text { Response-Effects: The Validity of } \\
\text { Response-Certainties and Response-Latencies }\end{array}$ \\
\hline $03-32$ & $\begin{array}{l}\text { Siegfried K. Berninghaus } \\
\text { Christian Korth } \\
\text { Stefan Napel }\end{array}$ & Reciprocity - an indirect evolutionary analysis \\
\hline $03-31$ & $\begin{array}{l}\text { Peter Albrecht } \\
\text { Cemil Kantar }\end{array}$ & $\begin{array}{l}\text { Random Walk oder Mean Reversion? Eine } \\
\text { statistische Analyse des Kurs/Gewinn-Verhältnisses } \\
\text { für den deutschen Aktienmarkt }\end{array}$ \\
\hline $03-30$ & $\begin{array}{l}\text { Jürgen Eichberger } \\
\text { David Kelsey } \\
\text { Burkhard Schipper }\end{array}$ & Ambiguity and Social Interaction \\
\hline 03-29 & $\begin{array}{l}\text { Ulrich Schmidt } \\
\text { Alexander Zimper }\end{array}$ & $\begin{array}{l}\text { Security And Potential Level Preferences With } \\
\text { Thresholds }\end{array}$ \\
\hline $03-28$ & Alexander Zimper & $\begin{array}{l}\text { Uniqueness Conditions for Point-Rationalizable } \\
\text { Solutions of Games with Metrizable Strategy Sets }\end{array}$ \\
\hline $03-27$ & $\begin{array}{l}\text { Jürgen Eichberger } \\
\text { David Kelsey }\end{array}$ & Sequential Two-Player Games with Ambiguity \\
\hline
\end{tabular}

